Rupkatha Journal on Interdisciplinary Studies in Humanities (ISSN 0975-2935), Vol. 10, No. 1, 2018 Special Issue on "Interrogating Cultural Translation: Literature and Fine Arts in Translation and Adaptation" In collaboration with the Department of English, Amrita Vishwa Vidyapeetham Guest-edited by Dr. Hari M G, Amrita Vishwa Vidyapeetham, Coimbatore, India DOI: https://dx.doi.org/10.21659/rupkatha.v10n1.11 Full Text: http://rupkatha.com/V10/n1/v10n111.pdf

\title{
The Juror-poet: a New Assessment of William Jones
}

\author{
Kush Sengupta \\ MPhil Research Scholar, University of Delhi. \\ ORCID oooo-0oo3-1088-1211. Email: littleg2monster@gmail.com,
}

Received September 17, 2017; Revised December 15, 2017; Accepted December 30, 2017; Published February o4, 2018.

\begin{abstract}
When we consider the career of William Jones, terms like "Indologist" or "Philologist" are chiefly used. Even in the canon of Jones himself, his juridical and academic writings occupy a higher pedestal than his literary endeavors. This has led to a lopsided view of this dynamic man. In this paper, I seek to propose a new appellation for Jones, preferring to call himself a "Jurist-Poet". The cognate term as I would believe can be best used to suit the ambivalent nature of his poetry. It is my contention that Jones was simultaneously in and out of the process of the Empire building and critical focus has been to stress on any one aspect of his character. The term that I propose to use for Jones would help to encapsulate the ambiguities that occur in him. It can only be achieved by a close reading of his poetry and using it to judge him as a true vehicle of the trajectory of his career.
\end{abstract}

Keywords: William Jones, Orientalism, Colonial India, Juror-Poet, Religious Hymns

The story of William Jones, the man who single handedly represents an important movement in $18^{\text {th }}$ century is remembered for his paradigm changing discoveries in the field of Indology. There is no doubt that his writings had a profound influence on the history of the relationship of East and West. But beyond the polemical writings and fascinating works, Jones has also left behind voluminous quantities of poetry which are overshadowed by his scholarly works. But, it is not to be assumed that his poetry is isolated from his scholarship. In fact, his poetry plays the role of an aesthetic vehicle for his ideas and meditations, often revealing hidden facets of his mind. This paper seeks to look into the poems of William Jones, particularly his hymns on the Indian gods written during his sojourn in India. But the paper will not just engage in an appreciation of his poems. Instead, his poetry will be read in context of his career. By his career, I mean not only as an Indologist but as well as a man of law. By a cursory look at his letters and memoirs one theme that becomes clear is the lifelong struggle of Jones to balance his Orientalist interests and his profession as a lawyer. I want to advance the notion of the Jurist-Poet to describe him. The phrase is my formulation and the idea is drawn from one of Jones's letter where he alludes to the figure of Minerva as a deity in whom the political and the creative fuses. (Teignmouth, 1807) It is my contention that the poetry served as a vehicle by which he combined his passion and profession.

(C) AesthetixMS 2018. This Open Access article is published under a Creative Commons Attribution Non-Commercial 4.0 International License (http://creativecommons.org/licenses/by-nc/4.0/), which permits non-commercial re-use, distribution, and reproduction in any medium, provided the original work is properly cited. For citation use the DOI. For commercial re-use, please contact editor@rupkatha.com. 
If we follow the letters and journal of Jones we find that before coming to India he had a lifelong struggle of balancing work and passion. The demands of law, more than once in his life had put a brief pause to his literary and artistic pursuits. In a letter written in 1771, he wrote how he had deferred writing an epic due to lack of time. He calls it polite literature, something which cannot be pursued due to his work pressure ((Teignmouth, 1807) In another letter he talks about how he contemplated giving up poetry because the profession of law demands one to be totally devoted to it. (Teignmouth, 1807) This would be a normal course of things because in England the subject of his interests; which he gives the umbrella term Oriental; is a distinct topic, but once in the colony it was no longer detached from life, it became a part of his own life. In London society, he also became entrenched in the Neo-Classical tradition of arts as explained by his pride at being regarded by both Pope and Joshua Reynolds. (Teignmouth, 1807) Being an amateur author, he used his contacts forged through his career to improve his literary projects.

The memos and letters written from the ship before alighting in India is full of the names of books that tries to read Indians as both subjects of law and poetry. (Teignmouth, 1807) He believed in the compound nature of men's identities, often contradictory. In his letter to Lord Ashburton, he calls him "spring and fountain", "author and father". He also states that the "coldness of our Northern language will hardly admit" such appellations. (Teignmouth, 1807) Therefore, it is in India, out of the sphere of the cold language, that he could focus on a hybrid identity for himself of a Juror- Poet. Indeed, he believed freedom to be the daughter and parent of virtue. In the same vein, he found Indians need to be ruled by an absolute power and yet sees the potential for justice and rationality in them. (Teignmouth, 1807) This may have to do with his own fascination with Oriental poetry, and the Platonic idea that anything that is aesthetically pleasing must have an essence of truth and order in it. Thus, an ambivalent and even dualistic view can be found in him about India. India afforded him an opportunity to reconcile the contradiction among him, on one hand he could serve his mother country as a judge and yet "promoting the happiness of the community in which he resided." (Teignmouth, 1807) by studying the antiquities about which very little research is done. Therefore, it is the notion that a demystification of the ancient knowledge of India would bring "happiness" to the community. Yet, there existed another contradictory chasm in his profession as an Indologist. The artefacts he dealt with did not belong to a past which is hermetically sealed from the present, instead, Hindoos were "living pieces of antiquity" (Teignmouth, 1807) Therefore, the Hindu community appeared to him, something living as well as lost, another set of contradictions, subject to laws and yet subject to history, a set of people who need firm authority and yet imbibe justice and rationality. This sense of continuity prevails in his poems as well as thoughts, a very romantic notion of a self-amnesic nation ready to be rejuvenated by a vigorous race from "fairer isles". Baidik Bhattacharya that the projects of William Jones "developed into an epistemic habit of the colonial state in the subsequent decades and saturated the daily business of running the empire." (2016, p. 679) When he founded the Asiatic Society of Bengal, attempts to study and translate Sanskrit texts was already underway. Lord Hastings, the Governor-general of Bengal was a pioneer in this regard. This would help to counter the charges that Jones took up the task of translating the Oriental works purely from a judicial point of view as the Lord Teignmouth suggests. (1809, p.33-34) Of course, the project had been a general British propaganda to administer India and is not the unique brain child of Jones. But in Jones, for the first time we find the project of using Indian material for creation of newer works of literature. Kurt A. Johnson describes Jones's role in hymns as a translator in the poem. He also says that he forms a mediator between the two cultures. He calls the process cultural translator drawing form Benjamin's "The task of the Translator" (2011, p.4) His project was also to "amuse" the "literati of Europe, from his superior abilities and learning." (Teignmouth, 1807) Such 
aspirations lay bare his desire to be a regarded poet which is often thinly veiled under the guise of his self-importance as a British Civil Servant posted in India. As Zak Sitter argues, that Jones's purpose was to reform and rejuvenate European poetry by drawing from Oriental poetry that does not imitate. (2008, p.3)

By 1785 , after a recuperative vacation through the upper provinces, he was already toying with the idea of the underlying similarity between the gods of Greece, Italy and India. Infact, the poem The Enchanted Fruit and the essay on the abovementioned topic was a fruit of his travels through upper India taken to recuperate from ill health. (Teignmouth, 1807) He calls his poems, "recreations" to be abandoned when his work intensified. (Teignmouth, 1807) In the essay, he validates the Hindu religion by equating it with the Western Paganism. But his admiration was not simply for a vanished past, but rather by putting the Hindus as the same pedestal as Greeks and Italians, he hoped that Indians would also follow the path of Christianity, as its European counterpart already has. (Teignmouth, 1807) This according to Jenny Sharpe united India with the Europe against the Islamic civilization. (1993, p.3) He withdrew from Calcutta society for a sojourn in Krishnanagar, to learn from the pundits of Nadia. From then, we see that it was no idle pursuit. Though set in idyllic surroundings, there was a fierce sense of purpose behind it. Initially made due to reasons of health, his stays in Krishnanagar became regular soon. While the rest of the British Calcutta, was engaged in idle pleasures as was the style of its time. Meanwhile, he continued his literary persuasions among his work and the task of learning Sanskrit. By 1789 he is actively translating plays, and even mentions taking time out of his profession as a lawyer for the purpose. (Teignmouth, 1807) In a letter to Doctor Patrick Ruffet, the complicity between his literary work and professional work is also revealed. The study of Arabic and Indian languages is connected to the discharge of his public duty (Teignmouth, 1807) and yet these stimulate him in repose to think about "literary subjects" (Teignmouth, 1807) On another instance in a letter he wrote on his English translation of Hindu and Muslim Laws is being carried out only for pleasure "of doing general good" and he also mentioned that he does not see himself as the "Justinian of India" (Teignmouth, 1807) But he is hungry for his fame as an oriental litterateur. One can sense the palpable anticipation in his letters when he encloses a piece of poetry along with it. The active desire to be appreciated as a literary artist compared to his own detached view of his profession help us reveal two sides of him.

Jones can be placed in what Edward Albert calls "The Age of Transition" between the neoclassical and the Romantic movement. This would also tie up very neatly with my contention that he is a Juror Poet. The jurist impulse would be the representative of the Neoclassical Impulse and on the other hand the poet would be the Romantic idea of poet. Johnson also achieves what Johnson calls the "bilateral process of cultural exchange." (2011, p. 6) The hymns to be dealt in this paper first appear in 1785 in Asiatic Miscellanies. The magazine aimed to publish "extracts from books published in Europe relating to India, of translations from Oriental authors and of poems and essays." Sometimes entries from gentlemen from India were also included. Jones is called as an Englishman who contributes "to the advancement of Oriental literature" (Teignmouth, 1807) Lord Teignmouth, whose collected works of William Jones accompanied by his letters form the chief source of my work appears in a great need to present the façade of William Jones as a conscientious civil servant. His critical estimate of his hymns is accompanied by a clarification

These compositions were the elegant amusements of hours of leisure and relaxation, which he never suffered to interfere with his public duties. They prove the versatility of those intellectual powers, which could immediately turn from the investigation of legal causes or the solution of abstruse mathematical problems. (1807, p.70) 
In fact, Jones's poems have faced relative neglect compared to his poems because, I believe the need to portray him as a man of science and law and not as an author who can be called a precursor to the Romantic movement. Kurt A. Johnson points out to what he calls Jones's "rhetoric of 'enthusiasm 'and 'devotion'" transcends scholarly interests. (2011, p.2) In fact, Jones himself struggled with his fascination all his life and whose evidences can be found in his hymns where after an initial flight of fancy, he comes back to his Englishness as if to remind himself his ultimate affiliations. Modern scholars have however seen Jones in a very different light. Johnson's helpful summation of the broad critical focus on Jones in recent years show us hoe Jones was appropriating India for the colonial project. Ironically, in his own time he was seen to have achieved just the opposite. Teignmouth's lengthy exposition about Jones's faith can be called symptomatic of the process where Jones's faith is defended ad nauseam. Therefore, Jones cannot ever be neatly compartmentalized into one category of conscientious civil servant or a man with libertine poetic ambitions. Instead I use the cognate term of Juror-Poet because I believe best describes him. Johnson's term of “cultural translator" (2011, p.7) is also very useful for our purpose. Because the figure of a translator is always intermediate, he is at once in the intersection of two language and cultural systems whose contradictions cannot ever be reconciled. Critics like Sola Pinto calls Jones's project a failure due to the complicated nature of Indian mythology, (1946) but I believe it has to do more with the fear of miscegenation and corrupting influence of India that a person dealing in Indian matters might fall into. It is no surprise that Lord Cornwallis who ruled for the better part of Jones's stay in India as Governor-general effectively banned mixed unions for English civil servants. ("British Family", 2013) Jenny Sharpe mounts a sharp critique to Said's analysis of Jones's project. She believes that Said's critique mounts a homogenous critique of the Orientalist project and fails to see how Indian knowledge systems were made complicit to European ones vis-à-vis the Islamic knowledge systems. (1993, p.1) Criticisms like that of Sharpe's also reveal the problematic stance of putting Jones in any one watertight category.

Now the paper would deal with the textual ambiguities in the Jones's hymns and briefly talk about some issues that emanate from the text. We find two tendencies in his poem, one to constantly reveal its affinity to the Classical which departicularizes the Indian experience. While talking about the flower Mellica, he however rejects the West and says that the Linnaean system of classification takes away the charm of literature. Jones had a complicated relationship with the Linnean system of classification by Interested reader can refer to the essay by Henry J. Noltie. (2013) He was also conscious of the "authenticity" of his "oriental" imagery for he must explain at lengths that ice and snow can be a part of the Bengal landscape.

Jones sees the past and present of India as two different and incongruous identities and this schizophrenic shift helps to sustain he idea of the Juror poet, the Juror ruling the present with the Enlightened ideas of the West and the poet reveling in the past and the exotic. The careful circumnavigation of the charge is idolatry is present at every step. In such a process, he does not actually do away with idolatry, instead puts Hinduism in the same pedestal as Greek or Roman religion. He also defends the varied nature of Pracriti or Shakti using a Pantheistic philosophy. He calls it nothing but a created nature and the polytheism arises from manifold personifications in literature. Therefore, he posits poetry as a genesis of the intellect of the Indian culture. In the "Hymn to Durga", we find Jones's deft use of the various names of Hindu gods for maximum poetic effect. He writes "Vasanta, vain of odorif rous rocks, /With cama, hors'd on infant breezes flew/...... /Vasabta barb'd the shaft and fixed the string;/The living Candarpa drew. (Jones, 1883, p.47) Lord Teignmouth mentions the unrealized epic by Jones where he plans to discuss the exploits of Brutus. But his ideas about Hindu gods made him introduce the machinery of the Hindu God's agency, a blasphemous suggestion, but that has to be undercut by the historical 
reality of India's domination by Britain. In his epic, also the Hindu mythological machinery is to be defeated by the Christian machinery. (1809)

Infact, he uses the polytheism to his advantage as it supplies him with imageries and tropes necessary for his poetry. It gives the poem its distinctly Oriental flavor and avoids verisimilitude with the Western poetry. Every image served him as a "poetical ornament" According to Kurt A. Johnson,

He advocated rejection of this recycled classicism, and championed the wider study of 'Asiatick' literature as a way of supplying 'a new set of images and similitudes' which 'future scholars might explain, and future poets might imitate'. In short, Jones was in search of a new poetics that could rejuvenate a tired English poesy. (2011, p. 2-3)

He also observes that "distractions of establishing regal government" and "allurements of vice" has been the cause of the origin of idolatry. (Teignmouth, 1807) Getting rid of the allurements of vice was also a project of Enlightenment and "Jones is following a well-trodden Enlightenment path." (Mukherjee, 1994-5, p.12) of Deism influenced by Hindu deities in his hymns. Deists were also often termed as "Freethinkers") where man can choose his own course of actions and his own morality. ("Deism", n.d., n.p.) In the end of most of his poems, he projects the idea of British Empire ruling over pagans. This strong interrogation of myths tie with his beliefs that "if [myths] brought under their rigorous scrutiny, it could yield knowledge of a past more ancient than any recoverable through conventional historic inquiry." (Lincoln, 2002, p.3)

Everywhere in his prefaces, he sees human intent and imagination in the poems. Therefore, it is not the Gods that are glorified in the hymns, it is rather the spirit of Indian poetry and in extension Jones as the mediator of the poems who is lauded in the poems. This would be a proof of his latent Republican sympathies or as A.J. Arberry calls him a "very advanced Whig" (1946, p.3) He also states that Teignmouth's biography of Jones goes at lengths "anxiety to make of his hero a prophet of Clapham evangelicalism." (1946, p.2) As, I would point out later in my paper, it is the autonomous poetic soul that Jones lauds in the poems, the industry of anonymous British subject and not the crown. This can also be a manifest of his Republican sympathies which is occluded in his poetry. On his preface to 'Two Hymns of Pracriti, Jones makes a distinction between Valmiki, who is said to have been divinely inspired vis-à-vis Kalidasa who seems to be more historically coherent. (Teignmouth, 1807) Another reason why he takes up Kalidasa over Valmiki is that according to him. Kalidasa is more popular, being accessed by Vaidyas. There is a conscious attempt on his smart to break the monopoly of the Brahmins and their hold on the Classical knowledge of Indias antiquity, to invade and conquer not only the "territorial space" but also the "epistemological space" (Johnson, 2011, p.5) which manifests in this process of systematizing knowledge and breaking the monopoly of Brahmins. A very strong link between his Republican poetic self therefore can be found to exist, one that is contemptuous of the shibboleth of established authorities. In the preface to the "Hymn of Lachsmi", he makes a direct argument between the complicity Hindu gods and the British Empire.

The allegories contained in the hymn constitute at this moment the prevailing religion of a most extensive and celebrated empire, and are devoutly believed by many millions, whose industry adds to the revenue of Britain and whose manners...nearly affect all Europeans who reside among them." (Jones,1772, p.79)

Infact, what he achieves in the poem is the projection of a pan-Indian idea of Hinduism. One can explain why Lord Teignmouth goes at lengths to defend Jones's literary project. One can almost find him juggling two professions of law and as a pioneer in literary archaeology, finding 
new avenues for Western poetry. The east gives one "liveliness of their fancy, and the richness of their invention." (Jones,1772,p.82) from which Western poetry that "...has subsisted too long on the perpetual repetition of the same images, and incessant allusions to the same fables "can benefit by...a new set of images and similitudes, and a number of excellent compositions would be brought to light, which future scholars might explain, and future poets might imitate (Jones,1772,p.82) Lord Teignmouth sees evangelical impulses in his poems, particularly the conclusion to "Hymn to Lachsmi" where he posits the Christian God over Lachsmi as merely nature and beguiling. (Teignmouth 1807) But no doubt there was a widespread thought that Jones has gone "Indian" or else the author would not spend lengthy passages defending the faith of the man as strictly Christian. In the poem itself, he uses both the indigenous name of Nycanthes, underlining the fusion of East and West.

It must be pointed out that on describing the story of Shiva and Parvati, there is no hint of eroticism or the sexual tension that prevails in Kumarsambhava by Kalidas, the inspiration for this hymn. Instead of lines like, "Between the partings of fair Uma's vest /Came hasty glimpses of a lovely breast/So closely there the kissing hillocks rose, /Scarce could the Lotus in the vale repose. (Griffith, 1853, p.8) We find, words like "sweet", "smooth footed", "lotos-handed". (Teignmouth, 1807, p.47) Thus we find Jones refashioning his stories through the lens of European gentility. Infact, by taking various names of Kama, Jones dilutes the raw sexual appeal of Kama's purpose. Jones is metatextually reticent of the eroticism of Shiva and Parvati, and "the rest, my song conceals:" (Teignmouth, 1807, p.51) Jones says as he forms a textual mediation between the stories and his audience. Thus, we can call the hymns a creative bowdlerization of Indian tales and he brilliantly uses the trope of poetic romanticism for his purpose. His motivations for this purpose may not only be harking to Europe. Instead, it may be considered by reimagining the Indian subjects in a distinctly Western form, he is modifying Indian literature itself, elevating it to the level of what he calls "polite literature" (Teignmouth, 1807)

In the "Hymn to Indra", the same cataloguing of various names occurs like a proclamation, but Jones cleverly inserts the name Dyupetir in the list of other names like Pulomaja, Purander or Sacra. (Teignmouth, 1807) Now as Jones himself explicates in the preface to the hymn, Dyupiter is another name for Jupiter or the King of the Greek gods. (citation) But Indra is not the omnipotent god, instead Jones alludes to the myth of Krishna holding the Govardan Mountain over the residents of Gokul to save them from the wrath of Indra and how 'the lord of thunder felt a mightier god". Elsewhere in his works Jones alluded to the supremacy of the Supreme God to the gods of the nature, which Indra represents. And Krishna, as he frequently alludes is none but Apollo, whose association with Sun ties him to the supreme being of the Western faith. Therefore, Krishna becomes the Supreme God for Jones lording over the nature god Indra. The allusion of Krishna as the 'shepherd boy' and "god in soul" (Jones, 1883, p 66) makes the parallel with Jesus even more apparent. The sun god or Surya in his poem also becomes an ambivalent figure. He is described as an all-powerful deity and there are strong tendencies to equate him with the JudeaoChristian god. When Jones describes Surya as, "though not from Brehma sprung" (Jones, 1883, p.77) he is consciously keeping him out of the cosmos of Hindu mythology, the brahman or Brahma being the "cosmic soul." ("Atman and Brahman, n.d., n.p.) By not being a part of Brahman, he is therefore an alien god or by implication a western import. It also may be the figure of enlightened Englishman who "draws orient knowledge from its fountain pure through caves obstructed long, and paths too obscure.” (Jones, 1883, p.77)

The last stanza of the song clarifies my contentions that the Sun god is emblematic of the British Empire. The concept is however not new. Historians and archaeologists have repeatedly 
pointed out the Surya's iconography as markedly non-Indian (Bhattacharji, 1970, p.224-28), The Indian Theogony) But jones makes it very apparent that, the agency of the Sun God or the empire can be a vehicle for "eternal truths"

Yes, though the Sanscrit song/Be strown with fancy's wreathes/And emblems rich, beyond low thoughts refin'd/Yet heav'nly truth it breathes. /With attestation strong (Jones, 1883, p.77, emphasis added)

The word attestation gains currency in this context. One can almost discern the juridical bent where the systems of selection and attestation can produce knowledge. One can almost feel Plato's analogy of the sun of the sixth book of The Republic working in the background where sun is the selected analogy for the good. (Burton, 2010) Therefore, although the poem is about an Indian god the conception of the Sun is predominantly Western and by relating to Plato's ideas, it has a strong sense of the Supreme being of Western philosophy. In other hymns also, he is distinctly Platonic in his approach, in the Hymn to Bhabani, the imagery of "golden ray" shooting through darkness

One another aspect of Jones's hymns is the abundance of the geographical details of India that abound in his poem. This is strikingly different from the conception of Jambudwip that occurs in Markendeya Puran, Srimad Bhagavatam and Mahabharata. (Agarwal 2012) Instead the landscape is what we now know to be a British conception, made up by the geographical explorations and desire to map India. This passage from "Hymn to Lachsmi" makes it abundantly clear where Jones's poem dreams up the conception of India as we know it now, of historical capitals of Magadh and Gour and actual geographical details of India which support the idea of one nation supported by the British. It is not my purpose to explicate at length about the process of empire building and knowledge formation by the colonial rule in India. But the actual geographical details and the invocation to Lachsmi is no coincidence. Other hymns lack such particularized geographical references. In this hymn, the condemnation of the Hindu gods is even more acute.

Clouded by priestly wiles

To senseless nature bows for nature's God

Now strech'd o'er ocean vast from happier isles,

He sees the wand of empire, not the rod:

Ah, may those beams, the western skies illume,

Dispers th' unholy gloom! (Jones, 1883, p.77)

The same tone pervads in "Hymn to Narayena" where the vision of Narayena is called "delusive pictures" (Jones, 1883, p.96) he in the end professes his faith for God or the one supreme god. The "Hymn to Ganga" almost becomes a panegyric to the united India under the British. In the span of one poem, Jones not only describes the river goddess but also the landscape through which it flows. In the process, he not only solidifies the idea of India, but uses the flowing river as one flowing stream of history. The poem incredibly fuses mythology to geographical realism. The poem becomes a celebration not of the goddess but the metaphor it serves for the Indian civilization. In fact, such a description of the river is perhaps an innovation, where he fuses the sacred and the profane together. There is also a pointed reference to the Islamic conquest of India and the destruction of temples. The poem particularly refers to Aurangzeb's destruction of the temple of Kasi Vishwanath. He is called a "ruffian king", "a ruthless bandit" who defaces the 
"shrines whence gift ethereal springs" (Jones, 1883, p.115) There can be two possible implications of the said event. One, he symbolically equates the Kashi Vishwanath as the place of Ganga's origin. Secondly, it might be a critique of Aurangzeb's violent religious policy of conversion and destruction of Hindu shrines. Jones posits the policies of the British Empire as a different one, markedly Orientalist. (Franklin, 2002, p.10) This may also be a sneaky policy recommendation which ties with Jones project of administering people by the laws of their own religion. It may also be seen as the outcome of the process of history where Aurangzeb's son "with discord rend his throne/ And his fair smiling realms be sway'd by nations unknown." (Jones, 1883, p.115) Here, Jones implicates Aurangzeb as well as Islamic rule that proceeded before the British rule as despotic and barbaric. The British rule is seen as the natural inheritor to the Hindu rule and the Islamic rule as "demon of his empire". Jenny Sharpe calls such an impulse in jones shaped by "sympathy and identity" and not "hostility and alterity" (1993, p.22) She also says that

Orientalist descriptions of an Indo-European origin and golden age of Hinduism identify the principles of modern colonialism-good government, high culture, wealth, and knowledge-as the essence of Hindu culture. The idea of Hindus sharing a distant past with Europeans thus demonstrates that India has fallen from an authentic, pure moment of civilization to which it now yearns to return. At the same time, any suggestion of a resemblance between Hindus and Europeans is restricted to a distant, and hence unthreatening, past. (1993, p.20)

One cannot help but notice the similarity of the "Hymn to Ganga" with Nathaniel Halhed's "The Brahmin and the River Ganges" written while he was engaged writing the famous $A$ Code of Gentoo Laws (1776). Michael J. Franklin's analysis of the "Brahmin and River Ganges" exhibits striking similarities as both the poems use Ganga "spout anti-Muslim propaganda; the degenerate Mughals not only corrupted justice, but disrupted commerce and culture, whitening the deserts with the bones of Indian kings." (2002, p.4)

Therefore, as we see Jones's poetry never follows any one straight trajectory. Instead it embraces myriad possibilities of conformism and subversion. The term Juror-Poet in this case gains critical currency to describe this man of rare abilities.

\section{References}

Agarwal, V. (2012, January 29). Decode Hindu Mythology. Retrieved from http://decodehindumythology.blogspot.in/2012/o2/jambudweep-global-island.html

Albert, E. (1984). History of english literature. Walton-on-Thames (Surrey): Thomas Nelson and Sons.

Arberry, A. (1946). New Light on Sir William Jones. Bulletin of the School of Oriental and African Studies, University of London, 11(4), 673-685. Retrieved from http://www.jstor.org/stable/608584

Bhattacharji, S. (1970). The Indian theogony: a comparative study of Indian mythology from the Vedas to the Purānas [PDF]. Retrieved from https://books.google.co.in/books?id=IDc9AAAAIAAJ\&printsec=frontcover\&source=gbs_ge_summary_r \&cad $=\mathrm{o} \# \mathrm{v}=$ onepage \&q\&f=false

Bhattacharya, B. (2016). On Comparatism in the Colony: Archives, Methods, and the Project of Weltliteratur. Critical Inquiry, 42 (Spring), 677-711. Retrieved March 16, 2016. 
"British India - A Family Story of The Raj”. (2013, January 29). retrieved from https://geneblanchette.wordpress.com/2013/o1/29/a-modern-indians-view-of-pre-independence-angloindians/

Caroll, B. J. (n.d.). Atman \& Brahman. Retrieved from http://www.world-religions-professor.com/atmanbrahman.html

Deism. (n.d.). Retrieved May 13, 2017, from http://www.allaboutphilosophy.org/deism.htm

Franklin, M. (2002). Cultural Possession, Imperial Control, and Comparative Religion: The Calcutta Perspectives of Sir William Jones and Nathaniel Brassey Halhed. The Yearbook of English Studies, 32, 118. doi:10.2307/3509044

Johnson, K. (2011). 'Lisping Tongues' and 'Sanscrit Songs': William Jones' Hymns to Hindu Deities. Translation and Literature, 20(1), 48-6o. Retrieved from http://www.jstor.org/stable/41306090

Jones, W. (n.d.). The Selected Poems Of Sir William Jones : Jones, William ... Retrieved May 13, 2017, from https://www.bing.com/cr?IG=5B501A13FD324BC99A138AE7937FFCCA\&CID=0315144262F26A8E18011EC3 63626B88\&rd=1\&h=4BzNjP3DTmoEssWQPpRig14dwoouPJkzLkokJH3A94U\&v=1\&r=https\%3a\%2f\%2farc hive.org\%2fdetails\%2fin.ernet.dli.2015.46704\&p=DevEx,5098.1

Jones, W. Poems, Consisting Chiefly of Translations from the Asiatick Tongues [PDF]

K. (1853). The Birth of War God: A Poem By Kalidasa [PDF]. Retrieved from https://archive.org/details/birthwargodapoeozgrifgoog

Lincoln, B. (2002). Isaac Newton and Oriental Jones on Myth, Ancient History, and the Relative Prestige of Peoples. History of Religions, 42(1), 1-18. Retrieved from http://www.jstor.org/stable/3176382

MUKHERJEE, S. (1994). "POLITICS AND POETICS : SIR WILLIAM JONES AND EIGHTEENTH-CENTURY VIEWS ON AESTHETICS.” Bulletin of the Deccan College Research Institute, 54/55, 35-46. Retrieved from http://www.jstor.org/stable/42930456

N. B. (2010, September 25). Plato's Metaphors: The Sun, Line, and Cave. Retrieved May 13, 2017, from https://outre-monde.com/2010/og/25/platonic-myths-the-sun-line-and-cave/

Noltie, H. (2013). On Pandanus leram and the other botanical binomials of Sir William Jones. Taxon, 62(6), 1268-1274. Retrieved from http://www.jstor.org/stable/taxon.62.6.1268

Sharpe, J. (1993). "The Violence of Light in the Land of Desire; Or, How William Jones Discovered India." Boundary 2, 20(1), 26-46. doi:10.2307/303175

Sitter, Z. (2008). William Jones, "Eastern" Poetry, and the Problem of Imitation. Texas Studies in Literature and Language, 5o(4), 385-407. Retrieved from http://www.jstor.org/stable/40755520

Teignmouth, L. (1807). Sir William Jones (Vol. 1-2) [PDF]. 